\title{
A Case Study on Marketing Practices of Small Ruminants in Arid Region of Rajasthan
}

\author{
Pankaj Lavania ${ }^{1}$, Kailash Chand Bairwa ${ }^{2 *}$, Garbar Singh $^{3}$ and M.P. Verma ${ }^{4}$ \\ ${ }^{1}$ Department of Animal Production, College of Agriculture, Agriculture University, Jodhpur, Rajasthan, INDIA \\ ${ }^{2}$ Department of Agricultural Economics, College of Agriculture, Agriculture University, Jodhpur, Rajasthan, INDIA \\ ${ }^{3}$ Senior Research Fellow, Farmers FIRST Project, Directorate of Extension Education, Agriculture University, Jodhpur, INDIA \\ ${ }^{4}$ Department of Animal Production, College of Agriculture, Agriculture University, Sumerpur-Pali, Jodhpur, Rajasthan, INDIA
}

*Corresponding author: KC Bairwa; E-mail: kailashiari@gmail.com

Received: 02 Aug., 2021

Revised: 03 Sept., 2021

Accepted: 09 Sept., 2021

\begin{abstract}
The present study was attempted to comprehend the small ruminant marketing system in Jodhpur district of Rajasthan. The primary data survey was conducted in three clusters viz., Manai, Binjvadia and Balrava of Jodhpur district during 2018-19. The study has covered 60 sheep and goat keeping households with 20 respondents from each clusters of Farmer FIRST programme. A structured questionnaire which had earlier to face the validity to collect the data from the sample respondents. The results of study revealed that majority of respondents $(65 \%)$ sold their animals when they needed cash for domestic use followed by due to scarcity of feeds and fodder (15\%) were the main reason to sell their animals. The marketing of sheep and goats completely unorganized and in the hands of large number of livestock traders and hardly attracted any interest of government. Important marketing channels were petty traders, village collectors and relatives and friends. Farmers were facing the problems of animal marketing. Even in absence of any governmental support for marketing system, they were ready to organize and innovate own inability farmers continuing with the present system of sheep and goat marketing, none of farmer satisfied with the prevailing marketing system of animals. Establishing cooperative societies for marketing of animals in the breeding tract would ensure timely and adequate supply of inputs and channelize the marketing process.
\end{abstract}

\section{HIGHLIGHTS}

(0 Existing marketing practices of sheep and goat in Arid region of Rajasthan.

(0 The marketing behavior of farmers.

0 Examine constraints in marketing of small ruminants.

Keywords: Small ruminants, marketing practice, Constraints, Arid region and Farmer FIRST programme

Livestock is an integral component of economic and social fabric of the rural masses in Rajasthan since crop farming is constrained by erratic rains and limited irrigation facilities, livestock is an adjacent farm enterprise in most part of the state especially in arid areas, which covers nearly $60 \%$ of the total geographical area of the state $(34.23$ $\mathrm{m}$ ha). This region is characterized by scanty and erratic annual precipitation (100-400 $\mathrm{mm}$ ), high evaporation rate $(1500-2000 \mathrm{~mm})$, high temperature and poor fertility of the soil. In addition to this frequent draught, extreme events triggered by climatic change may pose serious threat to survival of living being in arid region (Patidar et al., 2014). Animal husbandry plays an important role in livelihood security and economic sustenance of rural people by providing regular employment and income generation throughout the year and also provides security against risk in agriculture. Total population of sheep and

How to cite this article: Lavania, P., Bairwa, K.C., Singh, G. and Verma M.P. (2021). A Case Study on Marketing Practices of Small Ruminants in Arid Region of Rajasthan. J. Anim. Res., 11(05): 875-879.

Source of Support: None; Conflict of Interest: None 
goat (small ruminant) in Rajasthan is 79.03 and 208.4 lakh in numbers respectively, wherein contribution of Jodhpur district is about 8 per cent. The livelihood of rural people in arid regions of Rajasthan is primarily depended on rearing of domestic animals especially small ruminants viz., goat and sheeps.

Small ruminants (i.e. sheep and goats) make very valuable contributions (meat, milk, manure, skin etc.), socioeconomic relevance and stability to farming system. The profitability of small ruminant's farming depends upon the effective marketing of products. But, in India, marketing of sheep and goats is organized and involves various middlemen, unnecessary transportation, lack of awareness of markets, pricing structure, unorganized marketing facilities coupled with distress sale are the major reasons for not receiving the fair price for the animals by the farmers (Rathore, 1993). Moreover the adoption of improved technologies and innovative marketing strategy has been considered the key drivers for success of small ruminants rearing (Tanwar and Rohilla, 2012).

The Farmer FIRST as a concept of ICAR, New-Delhi is developed as farmer in a centric role for research problem Identification, Prioritization and conduct of experiments and its management in farmers' condition. The focus is on Farmer's farm, Innovation, Resources, Science and Technology (FIRST). The project is implemented since 2017-2018 in Jodhpur district of Rajasthan, rain fed agriculture is practiced in about $80 \%$ cultivable land and about $11 \%$ of the area in the district is irrigated (Singh, 2019). The present study is undertaken to appraise the social-economic status of small ruminant owners in arid region of Rajasthan, to recognize the marketing channels for selling small ruminants in arid region and to identify the constraints faced by small ruminant owners in arid region.

\section{MATERIALS AND METHODS}

The present study is based on primary data survey of marketing practices of small ruminants in arid region of Rajasthan. The multistage purposive sampling method was used to collect the information on various aspects of small ruminants. The Jodhpur district of Rajasthan was purposively selected for the investigation. Further, three clusters namely Manai, Binjvadia and Balrava have been purposively selected from two blocks of Jodhpur district.
Twenty small ruminant owners from each selected cluster were selected and interviewed as per pre-structured schedules. In this backdrop, the primary data survey was conducted in the year of 2018-2019 to provide the better understanding of marketing system for small ruminants. The information on social, economic, selling pattern and constrains aspects were collected, coding, decoding and scrutinized. After completion of this process, we have used basic statistical tools to obtain the outcomes.

\section{RESULTS AND DISCUSSION}

The socio-economic status of small ruminant owners in the study area is presented in Table 1. It was revealed from the table that majority of respondents were resided in nuclear type family $(61.60 \%)$. The highest nuclear family was found in Balarva (70\%) followed by Mania $(60 \%)$ and Binjvadia (55\%) in the study area. The results of education level indicated that 48.4 per cent respondents in study area were passed middle while 26.60 per cent upto metric class. The remaining 25 per cent respondents did not move to school in the study area.

Table 1: Socio-economic profile of small ruminant farmers in Arid Region of Rajasthan (In per cent)

\begin{tabular}{|c|c|c|c|c|}
\hline Parameters & $\begin{array}{l}\text { Manai } \\
(\mathrm{N}-20) \\
\end{array}$ & $\begin{array}{l}\text { Binjvadia } \\
(\mathrm{N}-20)\end{array}$ & $\begin{array}{l}\text { Balarava } \\
(\mathrm{N}-20)\end{array}$ & $\begin{array}{l}\text { Pooled } \\
(\mathrm{N}-60) \\
\end{array}$ \\
\hline \multicolumn{5}{|l|}{ Family Type } \\
\hline Nuclear & 60 & 55 & 70 & 61.60 \\
\hline Joint & 40 & 45 & 30 & 38.40 \\
\hline \multicolumn{5}{|l|}{ Education } \\
\hline Illiterate & 25 & 20 & 30 & 25.00 \\
\hline Middle school & 45 & 50 & 50 & 48.00 \\
\hline Secondary school & 30 & 30 & 20 & 26.60 \\
\hline \multicolumn{5}{|c|}{ Land holding (in Acres) } \\
\hline Landless (Nil) & 45 & 25 & 15 & 28.30 \\
\hline Marginal $(<2.5)$ & 30 & 40 & 45 & 38.30 \\
\hline Small (2.6-5) & 25 & 35 & 40 & 33.40 \\
\hline \multicolumn{5}{|c|}{ Experience in small ruminant farming (Years) } \\
\hline Low level (2-11) & 60 & 55 & 70 & 61.60 \\
\hline Medium level (12-21) & 40 & 45 & 30 & 38.40 \\
\hline \multicolumn{5}{|l|}{ Flock Size (Animals) } \\
\hline Small (1-15) & 45 & 25 & 15 & 28.30 \\
\hline Medium (16-30) & 30 & 40 & 45 & 38.30 \\
\hline Large $(>30)$ & 25 & 35 & 40 & 33.40 \\
\hline
\end{tabular}




\begin{tabular}{|c|c|c|c|c|}
\hline \multicolumn{5}{|l|}{ Total Income (₹) } \\
\hline $\begin{array}{l}\text { Low group (₹ } 12,500- \\
24,400)\end{array}$ & 45 & 50 & 40 & 45.00 \\
\hline $\begin{array}{l}\text { Medium group (₹ } \\
24,500-37,500)\end{array}$ & 30 & 30 & 35 & 31.70 \\
\hline $\begin{array}{l}\text { High group (₹ } 37,600- \\
50,000)\end{array}$ & 10 & 20 & 25 & 23.30 \\
\hline
\end{tabular}

Source: Author's own computation from surveyed data (20182019).

The land distribution pattern in the arid region indicated that 38.3 per cent farming community were fallen in marginal farmer category. Apart from this, about 33 and 28 per cent farmers in the study area belonged to small and marginal farmer category respectively.

In the study area, about 61.60 per cent farmers were having low level experience in rearing of small ruminant while 38.40 per cent farmers in medium level experience. It means majority of farmers $(61.6 \%)$ having low level of experience in small ruminant rearing. The small ruminant farmers were rearing flock (goat and sheep) in small (115 animals), medium (16-30 animals) and large (>30 animals) size categories at 28.30, 38.30 and 33.34 per cent respectively, in which majority $(38.3 \%)$ of farmers were having medium size of flock (16-30 animals) in Arig region of Rajasthan. In the study area, about 45, 31.70 and 23.30 per cent small ruminant farmers belong to low, medium and high income group of total annual income respectively. It means majority (45\%) of small ruminant farmers belong to low income group in arid zone of Rajasthan. Small ruminants rearing in arid zone of Rajasthan is an important economic activity of the rural people. Though, sheep and goats produce a variety of products, however for farmers, mainly surplus of kids \& lambs and adults, and to some extent milk and manure were sold in the market. Similar findings were also observed by Deoghare (2001); Panin and Mahabile (1997) and Kumar (2007) in their respective studies.

\section{Marketing channel and causes of selling small ruminants in Arid Region of Rajasthan}

Table 2 depicted results on selling reasons, identified marketing channels, selling methods and pricing procedures of small ruminants in arid region of Rajasthan. It could be seen from the table that small ruminant farmers sold their animals for the purpose of meat or breeding at different age. This is the major source of income for small ruminant animal owners in arid region of Rajasthan. They earned income in cash and kind from the sold out of small ruminants and their products (milk and dung). However, component income from sold out of milk and dung are largely in kind in the arid region of Rajasthan. Generally, farmers retained female animals as a replacement of stock and male were sold for meat purpose. Farmers were asked to offer sale of their animals. Majority of farmers preferred to sell kid/lamb of small ruminants at earlier age after weaning. It was pointed out in the Table 2 that majority of respondents $(65 \%)$ sold their animals when they have need of cash for domestic work. Other reasons were scarcity of feeds and fodder (15\%), surplus animals $(12 \%)$ and fear of sickness $(8 \%)$. Therefore, farmers were not interested in raising the male $\mathrm{kid} / \mathrm{lamb}$ up to the economic age of slaughter in this region. Further, farmers were also faced constrained in managing the grown up male/lamb due lack of sufficient and separate housing facilities for them. Efforts should be made to encourage farmers to rear the $\mathrm{kid} / \mathrm{lamb}$ up to their optimum age of slaughter i.e. 6-8 months. The adult females sold for slaughter were mostly culled ones. These observations were in close proximity to the findings reported by Rathore (2006).

Table 2: Marketing channels and selling reasons of small ruminants in Arid Region of Rajasthan (In per cent)

\begin{tabular}{|c|c|c|c|c|}
\hline Particulars & $\begin{array}{l}\text { Manai } \\
(\mathrm{N}-20)\end{array}$ & $\begin{array}{l}\text { Binjvadia } \\
\text { (N-20) }\end{array}$ & $\begin{array}{l}\text { Balarava } \\
(\mathrm{N}-20)\end{array}$ & $\begin{array}{l}\text { Pooled } \\
(\mathrm{N}-60)\end{array}$ \\
\hline \multicolumn{5}{|l|}{ Reasons for sale } \\
\hline $\begin{array}{l}\text { Urgent need of } \\
\text { cash for domestic } \\
\text { responsibilities }\end{array}$ & 65 & 75 & 55 & 65 \\
\hline $\begin{array}{l}\text { Scarcity of feed and } \\
\text { fodder }\end{array}$ & 20 & 15 & 10 & 15 \\
\hline Surplus animals & 20 & 10 & 15 & 12 \\
\hline Fear of sickness & 10 & 10 & 5 & 8 \\
\hline \multicolumn{5}{|c|}{ Identified Marketing Channel } \\
\hline Petty trader & 75 & 70 & 65 & 70 \\
\hline Village collectors & 25 & 20 & 15 & 20 \\
\hline Relative and friend & 10 & 10 & 10 & 10 \\
\hline
\end{tabular}

Source: Author's own computation from surveyed data (20182019). 
There are various marketing channel for selling of live small ruminant in arid region of Rajasthan. However, majority of respondents used three marketing channels viz., petty trader, village collector and friends/relative for selling kind/lamb of small ruminants in this region. A perusal of Table 2 indicated that 70 per cent respondents were sold their small ruminants through petty traders as one of the major marketing channels. Further, 20 and 10 per cent respondents were sold out their live small ruminant through village collectors and relative/friends in arid region of Rajasthan. The petty traders are regularly visited into villages for buying small ruminant animals from the farmers. It might be due to lack of market in near areas. These petty traders sold these animals to nearby markets or in animal fairs. The results were with close proximity to the findings of (Lavania and Singh, 2008) in their study of goat marketing practices followed in southern part of Rajasthan.

\section{Pricing and Selling Pattern of Small Ruminants}

The selling price and selling pattern of live small ruminants in the study area is presented in Table 3. There we have found out two ways namely per head and per pair for selling their live small ruminants in arid region of Rajasthan. It was revealed from the table that 75 per cent farmers were sold their live small ruminants in per head pattern while 25 per cent in per pair. In spite of sheep and goats being the source of high value of food, their price was not decided on body weight basis. The common method for price fixation of live animals in the villages was mutual bargaining and open sale system. Different buyers used different basis for deciding the price of live animals. The price of live small animal was mainly decided based on body weight of the animals. But there was no facility for weighing the animals. Therefore, traders used Hattha system to judge the body weight of buying animal in the study area. In this system, traders estimate the body weight of animal by holding it on its back, but the farmers remained unaware of the weight of animal. The other basis of valuing the animals were breed, colour and body size. It was indicated in the table that 70 per cent respondents in the arid region were sold their live small ruminants based on their body weight while 20 and 10 per cent on the basis of animal age and breed.
Table 3: Pricing and Selling Pattern of Small Ruminants in Arid Region of Rajasthan (In per cent)

\begin{tabular}{lllll}
\hline Particulars & $\begin{array}{l}\text { Manai } \\
\text { (N-20) }\end{array}$ & $\begin{array}{l}\text { Binjvadia } \\
(\mathbf{N}-20)\end{array}$ & $\begin{array}{l}\text { Balarava } \\
(\mathbf{N}-20)\end{array}$ & $\begin{array}{l}\text { Pooled } \\
(\mathbf{N}-60)\end{array}$ \\
\hline Unit of sale & & & & \\
\hline Per head & 75 & 65 & 85 & 75 \\
Per pair & 25 & 35 & 15 & 25 \\
\hline Pricing of animals & & & & \\
\hline Body weight & 80 & 60 & 70 & 70 \\
Breed (Colour \& & 10 & 10 & 10 & 10 \\
Body configuration) & 25 & 20 & 15 & 20 \\
Age & 25 & & & \\
\hline
\end{tabular}

Source: Author's own computation from surveyed data (20182019).

Most of the farmers were not satisfied with the present marketing system followed in this region and they expressed that middlemen were not helpful in marketing of animals. Majority of farmers felt that they get lower price for their animals because of distress sale and poor health conditions of animals. Farmers never bargained for price of their animals on the basis of value of products. These observations are in close proximity to the findings reported by Pania and Mahabile (1997), Ramesh et al. (2012).

\section{Constraints faced by farmers in selling of small ruminants animals}

The problems encountered by farmers in the study area are presented in Table 4. It was revealed from the table that lack of transparency in trading $(70 \%)$ is the major trouble faced by farmers followed by high marketing fee/ commission agent (40\%), very poor access to market $(30 \%)$ and prevalence of collusive activity of trader $(20 \%)$ during selling of small ruminants in arid region of Rajasthan. The farmers' weakest point was that they did not have access to market/ price information, had no idea about the demand and supply situation. Having low education level and exposure, farmers were not able to use the available information in taking right decision. Therefore, the farmers were not in position to negotiate/ bargain for price with the trader. The results were with close proximity to the findings of Shalendra et al. (2014) in their study of goat marketing system in Rajasthan. 
Table 4: Constraints faced by farmers in marketing of small ruminant in Arid Region (In per cent)

\begin{tabular}{lllll}
\hline Parameters & $\begin{array}{l}\text { Manai } \\
\text { (N-20) }\end{array}$ & $\begin{array}{l}\text { Binjvadia } \\
\text { (N-20) }\end{array}$ & $\begin{array}{l}\text { Balarava } \\
\text { (N-20) }\end{array}$ & Pooled \\
\hline $\begin{array}{l}\text { High marketing fee/ } \\
\text { commission agent }\end{array}$ & 90 & 50 & 60 & 40 \\
$\begin{array}{l}\text { Lack of transparency in } \\
\text { trading }\end{array}$ & 80 & 60 & 70 & 70 \\
$\begin{array}{l}\text { Very poor access to } \\
\text { market }\end{array}$ & 30 & 25 & 35 & 30 \\
$\begin{array}{l}\text { Prevalence of collusive } \\
\text { activity of trader }\end{array}$ & 25 & 30 & 40 & 20 \\
\hline
\end{tabular}

Source: Author's own computation from surveyed data (20182019).

\section{CONCLUSION}

The study on marketing practices revealed that majority of farmers sold their animals on immediate requirement of cash for fulfil their domestic responsibilities. The marketing of sheep and goats completely unorganized and in the hands of large number of livestock traders and hardly attracted any interest of government. In the absence of any support of government and there to organize and innovate own inability farmers continuing with the present system of sheep and goat marketing, none of farmer satisfied with the prevailing marketing system of animals. The farmers must be educated towards the awareness programme being implemented by Government.

\section{ACKNOWLEDGEMENTS}

Authors are thankful to the Principal Investigator of ICAR funded Farmer FIRST project, Agriculture University, Jodhpur for providing necessary facilities and logistics support for conducting this study. Authors are also thankful of small ruminant owners for participation in this study.

\section{REFERENCES}

Deoghare, P.R. 2001. Marketing of Barbari goats in Etawah district of Uttar Pradesh. Indian J. Small Ruminants, 7(2): 96-101.

Kumar, S. 2007. Commercialization of goat farming and marketing of goats in India. Central Institute for Research on Goat, Makhdoom, Mathura,UP, pp. 5-107.

Lavania, P. and Singh, P.K. 2008. Goat marketing practices in southern Rajasthan. Indian J. Small Ruminants, 4(1): 99-102.

Panin, A. and Mahabile, M. 1997. Profitability and household income contribution of small ruminants to small scale farmers in Botswana. Small Rumin. Res., 25: 9-15.

Patidar, M., Patel, A.K., Mishra, A.K., Sirohi, A.K., Kumawat, A.S., Meghwal, P.R. and Roy, M.M. 2014. Improving Livelihood of farmers through Livestock Interventions in Nagaur District of Rajasthan. Central Arid Zone Research Institute, Jodhpur, pp. 56.

Ramesh, D, Meena, H.R. and Meena, K.L. 2012. Analysis of small ruminants' market system in different agro climatic zones of Southern India. Vet. World, 5(5): 288-293.

Rathore, M.S. 2006. Status and strategies for marketing of goat and sheep, their meat and meat products. In: Proceeding of National workshop cum seminar of Central Institute for Research on Goat, March 4-5, 2006. Makhdoom, UP-India. pp. 45-47.

Rathore, M.S.1993. Marketing of goats in Rajasthan. $1^{\text {st }}$ ed., Classic Publishing House, Jaipur, pp. 34-36.

Shalendra, K., Kareemulla, K. and Rao, R.C.A. 2014. Goat marketing system in Rajasthan. Indian J. Agric. Mark., 23(3): $150-167$

Singh, I. 2019. Annual Progress report of farmer FIRST programme, Directorate of Extension Education, Agriculture University, Jodhpur, pp. 5-6.

Srivastava, S.P. and Saraswat, B.L. 2006. Marketing of Jamanapari goats in its native tract. Indian J. Anim. Res., 40(2): 127-130.

Tanwar, P.S. and Rohilla, P.P. 2012. Goat marketing practices adopted by farmers in Jaipur district of Rajasthan. Indian $J$. Small Rumin., 18(1): 121-124. 
